\title{
Ekphrasis in Four Poems About Urns and Vases
}

\author{
Alvaro Cardoso Gomes \\ Department of Portuguese Literature, University of São Paulo, São Paulo, Brazil
}

Email address:

alcgomes@uol.com.br

\section{To cite this article:}

Alvaro Cardoso Gomes. Ekphrasis in Four Poems About Urns and Vases. International Journal of Applied Linguistics and Translation. Vol. 7, No. 3, 2021, pp. 109-115. doi: 10.11648/j.ijalt.20210703.14

Received: July 22, 2021; Accepted: August 16, 2021; Published: September 4, 2021

\begin{abstract}
In this interdisciplinary article, we apply the concept of the rhetorical figure of ekphrasis. We will show, in a first instance, that it can be understood as any type of description serving to bring to the reader's eye something that is distant; however, with the passage of time, this rhetorical figure will be understood in a more complex way, that is, a type of description that targets only and exclusively artistic objects. This new conception will imply that ekphrasis will change from a simple figure that performs a "mimesis of nature" to a rhetorical figure that performs a "mimesis of culture". Next, we will analyze poems by four poets (Theocritus, Greek, John Keats, English, Alberto de Oliveira, Brazilian and Wallace Stevens, American), each of whom describes a specific sculptural object, either a classical Greek urn, with ornaments or a common, bare jar. We show that there are modifications of the descriptive look, from a classical figuration, through the romantic, and the Parnassian, to the parodic, in the modernist or postmodernist conception, which, using a readymade, in Marcel Duchamp's sense, deconstructs the relation between the artistic object, the poet and the reader, and thus implies the dismantling of the traditional convention of the rhetorical figure of ekphrasis.
\end{abstract}

Keywords: Ekphrasis, Vase, Convention, Classic, Post-modern

\section{Introduction}

We will open this article with the conceptualization of the rhetorical figure of ekphrasis and its historical evolution, from its conception as a mere description to its more complex conception as a description of an object of the plastic arts. Next, we will work with four ekphrastic pieces by Theocritus, Keats, Alberto de Oliveira, and Wallace Stevens, which share the theme of describing vases and the resonances that result from them.

\section{A Concept of Ekphrasis}

Etymologically, ekphrasis (from the Greek ek, "to the end" and phrazô, "to make understood, show, explain") can be defined as "the action of going to the end" [2]. Approximately in the third century CE, it acquired the generic sense of description. According to Françoise Desbordes, such description has the following characteristics:

It revels people, events, times, places, animals, plants, according do precise rules concerning the aspects to be examined and the order in which they are examined. The style will be adapted to the subject, and most importantly, one will endeavour to put before the eyes of the listener what one is talking about - the rhetoricians call this quality energeia [evidentia in Latin] (emphasis in the original) [4].

This type of discourse must, therefore, have some essential qualities, if its aim is to have an expressive effect on the recipient. In the view of the Alexandrian sophist Aelius Théon, it needs to have "the clarity, above all, and the visibility that almost makes you see what is exposed" $[4,16]$. In other words, through verbal communication, it serves to bring what is distant and thus inaccessible, closer to readers, preferably by addressing their eyes. However, if we identify the ekphrasis with description pure and simple, we will verify that such identification, in a way, even if correct, will take from this rhetorical figure its specificity, as if it corresponded only to any type of enumeration of "people, events, moments, places, animals, plants".

Over time, this first sense is added by a more specific one, in order to determine the true sense of the ekphrasis. Instead of just referring to mere description that presents itself as a counterfeit of the natural world, with the consequent enumeration of beings and objects, it begins to acquire a more restrictive, but more significant sense: as that kind of 
description in which verbal expression seeks to be equivalent to non-verbal expression, by using rhetorical devices that can mimic the technical devices used by painters in the composition of their canvases.

The conception of literature as similar to painting, fulfilling the precept of Horace's ut pictura poesis [6], rests on the classical principle that poetry (and by extension, literature in general) must be a mimetic art by excellence, that is, it is convenient for the poet to reproduce the natural world through words, but seeking to use the painters' own expedients, such as the enumeration of beings and objects, objectivity, visualization, and chromaticism.

\section{Ekphrasis as Mimesis of Culture}

Over time, ekphrasis came to designate not only the simple description of beings and objects in the real world, but also and, above all, the description of beings and objects contemplated by plastic or graphic arts. Leaving the real world itself in the background, this rhetorical figure focuses his attention on the world represented within the limits of a canvas, a sculpture, a photograph. By constituting an "ekphrasis is the verbal representation of graphic representation" [5], this would result in ekphrasis becoming more a mimesis of culture than a mimesis of nature [3]. In other words, ekphrasis uses one representational medium to represent another, which mimics real world beings and objects. It should be understood, however, that this is not about making the poem a mere passive reproduction of a painting or a sculpture, or just a "classic pictorial poem", that is a poem about a painting or sculpture that imitates the selfsufficiency of the object. According to Brazilian critic Massaud Moisés,

Poetic ecfrasis is a recreation, as much as expressing the effect of a natural landscape on the poet's sensibility: it is a parallel reality, not his image in a flat mirror [11].

It may be said that "ekphrastic literature typically delivers from the pregnant moment of graphic art its embryonically narrative impulse, and thus makes explicit the story that graphic art tells only by implication" (emphasis in the original) [5].

This is what led the American theorist to conclude that ekphrasis, in addition to representing only the fixity of objects in a painting, for example, imposes to graphic art a rhythm that is both narrative and prosopopeic, and which, due to the limits of the nonverbal sign, it usually represses, insofar as "the pictorial signifier is empty, as it has no meaning". And this sense is only reached when a "transfiguration, a metamorphosis takes place, in which the empty signifier of painting is replaced by the full signifier of poetry" [11]. As a result, the ephphrastic description makes the silent figures on a canvas or a sculpture speak [6].

Ekphrasis ends up telling readers and/or listeners an unknown story, by bringing to their eyes and/or ears something that is far away. Or it may even bring a known story, like those present in classic paintings, but revealing something that they only suggest or imply. It should be added that this rhetorical figure introduces the essentially spatial object of graphic art into the temporal world, by giving it movement and, consequently, the status of narrative. The ekphrasis, therefore, "typically represents the arrested moment of graphic art not by re-crating its fixity in words but rather by releasing its embryonically narrative impulse" [11].

\section{Urns \& Vases}

\subsection{Theocritus}

Let us now analyze four ekphrastic texts, which have as their starting point the description of urns and vases. The first is by the Greek poet Theocritus (300 BC-, $275 \mathrm{BC}$ ):

Idyl I - The Death of Daphinis

And I'll give thee, first,

To milk, ay thrice, a goat - she suckles twins,

Yet ne'ertheless can fill two milkpails full;-

Next, a deep drinking-cup, with sweet wax scoured,

Two-handled, newly-carven, smacking yet

0 ' the chisel. Ivy reaches up and climbs

About its lip, gilt here and there with sprays

Of woodbine, that enwreathed about it flaunts

Her saffron fruitage. Framed therein appears

A damsel ('tis a miracle of art)

In robe and snood: and suitors at her side

With locks fair-flowing, on her right and left,

Battle with words, that fail to reach her heart.

She, laughing, glances now on this, flings now

Her chance regards on that: they, all for love

Wearied and eye-swoln, find their labour lost.

Carven elsewhere an ancient fisher stands

On the rough rocks: thereto the old man with pains

Drags his great casting-net, as one that toils

Full stoutly: every fibre of his frame

Seems fishing; so about the gray-beard's neck

(In might a youngster yet) the sinews swell.

Hard by that wave-beat sire a vineyard bends

Beneath its graceful load of burnished grapes;

A boy sits on the rude fence watching them.

Near him two foxes: down the rows of grapes

One ranging steals the ripest; one assails

With wiles the poor lad's scrip, to leave him soon

Stranded and supperless. He plaits meanwhile

With ears of corn a right fine cricket-trap,

And fits it on a rush: for vines, for scrip,

Little he cares, enamoured of his toy [15].

The goatherd refers to the vase, describing everything from its perfect shape to the carved images, but, as it is an ephphrastic poem, it does not restrict itself only to listing the descriptive elements. What he does, in addition to talking about the format, is to point out three distinct scenes, which give the animation and life that the illustrations of the vase, for obvious reasons, do not contain. The scenes, unconnected and quite disparate, focus on the beautiful girl, requested by two young men, the old fisherman who drags a heavy net, and a vineyard, which should be watched over by a boy, 
against the harassment of foxes. In the three illustrations, what is observed is that the decorative elements appear in the form of narratives. In the loving contour scene, the girl leads the young people to confront each other ("they rival with words"), because she, all flirtatious, now smiles at one, now, at the other, thus provoking discord. In the work scene, an old man, in giving himself to a task more worthy of a young man - dragging the very heavy hammock over a rocky ground - ends up suffering a lot from it. In the last of the scenes, a boy charged with guarding a vineyard, instead of giving himself to his due work, entertains himself by building a net to catch locusts, and the result is the animals attacking the fruit and snack from his sack, due to his excessive enchantment with the object he builds.

Theocritus, when showing the suffering in Love and in rough work, sees as the only solution for man the surrender to manual work, in everything similar to the artistic task, which, in this case, leads the young man to forget about the petty reality. This is what Brazilian critic Érico Nogueira observes about Theocritus' poetics:

The contrast between the uselessness of loving care and the suffering of manual labor, on the one hand, and, on the other, the pleasure of an activity, such as braiding a cricket cage, so frankly alluding to the poetry (p. 56) [13].

The ekphrasis in Theocritus is at the service, in the foreground, of the description of an object of the plastic arts, of the animation of its inert figures, thus imprinting on them a narrative principle and, in the second level of the valorization of the artistic work itself. Hence the vase is offered to Tirsis, if he knows how to sing as well as Cromis the Libyan, that is, the artifact, which will serve as a gift, will be equivalent to the song. In artistic terms, the vase made of wood, with its beautiful inscriptions, has the same value as a musical piece, thanks not only to its ornaments, but because they make the viewer become witness to old stories, which win color, shape and movement. And all this thanks to the ekphrasis that transforms non-verbal signs into verbal ones, placing before our eyes a sculptural piece of antiquity.

\subsection{Keats}

The poem "Ode on a Grecian Urn" (1819), by English poet John Keats (October 31, 1795, London - February 23, 1821, Rome), contemplates an object of classical tradition:

Ode on a Grecian Urn I

Thou still unravish'd bride of quietness,

Thou foster-child of silence and slow time,

Sylvan historian, who canst thus express

A flowery tale more sweetly than our rhyme:

What leaf-fring'd legend haunts about thy shape

Of deities or mortals, or of both,

In Tempe or the dales of Arcady?

What men or gods are these? What maidens loth?

What mad pursuit? What struggle to escape?

What pipes and timbrels? What wild ecstasy?

II

Heard melodies are sweet, but those unheard
Are sweeter; therefore, ye soft pipes, play on; Not to the sensual ear, but, more endear'd, Pipe to the spirit ditties of no tone:

Fair youth, beneath the trees, thou canst not leave Thy song, nor ever can those trees be bare;

Bold Lover, never, never canst thou kiss, Though winning near the goal yet, do not grieve; She cannot fade, though thou hast not thy bliss, For ever wilt thou love, and she be fair! III

Ah, happy, happy boughs! that cannot shed Your leaves, nor ever bid the Spring adieu; And, happy melodist, unwearied,

For ever piping songs for ever new; More happy love! more happy, happy love! For ever warm and still to be enjoy'd, For ever panting, and for ever young; All breathing human passion far above, That leaves a heart high-sorrowful and cloy'd, A burning forehead, and a parching tongue.

IV

Who are these coming to the sacrifice?

To what green altar, O mysterious priest, Lead'st thou that heifer lowing at the skies, And all her silken flanks with garlands drest? What little town by river or sea shore, Or mountain-built with peaceful citadel, Is emptied of this folk, this pious morn? And, little town, thy streets for evermore Will silent be; and not a soul to tell Why thou art desolate, can e'er return. V

O Attic shape! Fair attitude! with brede Of marble men and maidens overwrought, With forest branches and the trodden weed; Thou, silent form, dost tease us out of thought As doth eternity: Cold Pastoral!

When old age shall this generation waste, Thou shalt remain, in midst of other woe Than ours, a friend to man, to whom thou say'st, "Beauty is truth, truth beauty," — that is all Ye know on earth, and all ye need to know [8].

Composed of five stanzas and configuring itself as an authentic ekphrastic piece, the poem has a voice that imposes a narrative impulse on fixed images in a sculptural object, the Greek urn. Further, it makes inanimate figures come to life, as if the poet recalled an immemorial and paradisiacal time that of the pagan classical world. However, a first question arises. Is the urn referred to by the poet only imagined, a product of his idealization, or is it a real urn, actually contemplated in some museum, so that the non-verbal signs were translated into verbal signs, for the expansion of its implied meanings? Although this question of reality or not matters little, we have opted for the second hypothesis, based on Keats's drawing of the "Urn of Sosibios". It is a marble Neo-Attic devotion crater, signed by Sosibios, a sculptural piece from the Louvre Museum, which the poet found in 
Henry Moses' work A Collection of Antique Vases, Altars, Paterae [13, 12]:

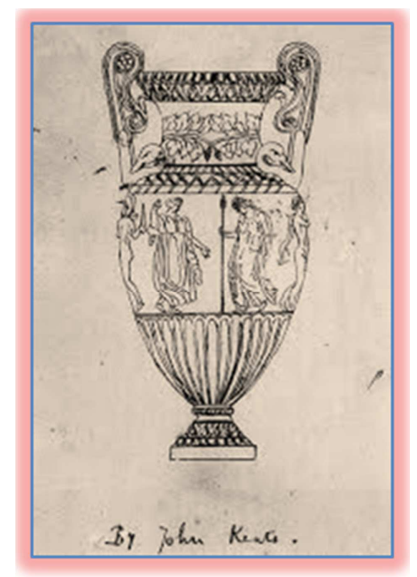

Figure 1. Greek Urn.

In describing the Greek urn, Keats follows a poetic tradition that most likely goes back to the Theocritus of "Idyll I", whose ekphrastic creation in the core of his poem may or may not have served as a model for the English poet. What differentiates both texts is the serene and somewhat ironic tone of Theocritus, as opposed to the inflamed, emotional tone of the English romantic poet, who apostrophizes the urn and the figures, establishing a dialogue aimed at finding answers to his transcendental concerns about the life, death, the ephemeral and the eternal.

As for the structure, the poem has five stanzas, with ten lines each, and the rhymes follow the following scheme: a quartet $(\mathrm{ABAB})$ and a sextet (CDECED). There is an introit, in which the subject of the enunciation seeks to awaken the urn from its ancestral sleep, and an epilogue, in which the urn finally manifests itself, answering the rhetorical questions in the preamble. The ode offers two extremes: the classical quartets and sextets of romantic poetry, as if the poet wanted to affirm at the same time the rescue of Classicism, which serves as a model for his text, and fidelity to Romanticism, the literary movement in which he pontificated. A balance is thus perceived between attic clarity, serenity, the recovery of pagan entities and emotional raptures, as if the aesthetic object served not only as a bridge between two great aesthetics, to unite the past with the present, but also to make with the present being animated by the breath of the past, implying that the poet not only rescued tradition, but also inserted himself in it, as an authentic child of his time.

But, for that, Keats needs to animate the artifact with life, which happens in the poem's Introit, through the resource of the apostrophe. The urn is the "foster-child of silence", for two main reasons: it is made of marble, which explains its stillness and silence, and created by an artist who knew how to express himself through non-verbal signs, leaving some inscribed in the artifact. stories yet to be told, which will only be developed in their entirety, when animated by the poet's breath. In view of Heffernan, Keats does not simply represent the lovers as figures deployed in space. Instead he calls them into life as his auditors, and to these imagined auditors he speaks a language of temporality [5].

From the fifth verse of the first stanza, the poet, still invoking the artifact, asks a series of rhetorical questions regarding the images recorded in the urn, as if he wanted to interpret them through interrogations, which will be answered in the poem's development. Thus, he refers to legends, deities, mortals, lost in time and in the valleys of Arcadia, the mad pursuit, the music of "pipes and timbres", the "wild ecstasy". In the second stanza, the poetic subject changes interlocutor, as he turns to the flutes, imploring them to sound, not to the sensory ears, but to those of the spirit, "Not to the sensual ear, but, more endear'd,/Pipe to the spirit ditties of no tone", as if they constituted a platonic absolute. From this invocation a synesthetic movement takes place, since the sensory appeal causes the appearance of a sensation of another order, the visual, since, right after, the apostrophe is directed to the "fair youth" that sings. In that instant, Keats seems to suspend time, freezing the images, for the song does not stop, the trees do not lose their leaves, the lover will never kiss the beloved, although all this does not lead to the loss of the impulse of desire. This is why lovers will love each other forevermore, despite, or because, the delight has not been fulfilled: "She cannot fade, though thou hast not thy bliss,/For ever wilt thou love, and she be fair!"

The figures live, thus, under the sign of eternity, suspended in timeless time, which makes their actions endure and melodies remain new and fresh. Hence the expression "for ever" appears repeated five times in opposition to "nor ever", but creating a false opposition, since the "forever" represents what will remain for eternity - full youth, heat, passion - has as a complement the "never", referring to the leaves of the trees that will never say goodbye to the eternal spring.

In the fourth stanza, the poetic self re-apostrophizes the urn, asking it questions about the sacrifice of a heifer by a mysterious priest, thus abandoning one of the motifs drawn on the artifact, to concentrate on another, which he will soon also leave back. In fact, from the sacrifice represented, the gaze now stops at a small town, silent and desolate, on the edge of a beach or a river, or even surrounded by walls. At this point in the poem, the poet only makes a few guesses, unable to objectively describe the city (there are doubts about its location and structure) and unable to understand why it is deserted either. Whoever could break the silence and tell this story in all its completeness will never return in the suspended moment, which will prevent the poet's doubts from being cleared up. It is believed that, with this, Keats remains with his interrogations on the threshold between the real figures, immortalized in the space of the non-verbal signs of the urn, and his imagined actions, suggested by the poetic word. A counterpoint between the frozen past and the active present is thus experienced.

The poem rests on a paradox: if, on the one hand, the urn preserves forever the youth of the lovers ("for ever young"), because it is made of marble; on the other hand, it makes them inanimate and lifeless, also because it is made of marble. Living implies being a slave to time, which would 
lead beings to complete the act of love, the song to end, the leaves of the trees to fall and, finally, death to establish its empire.

The urn is an artifact capable of suggesting a history that lasts beyond the time of its creation - not by chance, the poet calls it a "sylvan historian"; after all, she tells and, at the same time, freezes a caption through the beauty of her images. However, we are back to the starting point: the urn and/or its drawings is silent, does not speak or will only speak through the words of the poet. As he does not speak, his figures do not move, they remain trapped in the space of stillness, without the manifestation of time that could awaken them to life and, consequently, to death: "When old age shall this generation waste".

Eternity will only be conquered in the frozen space of the marble, in which the figures outline, insinuate gestures of passion and action, but they do not end them: "Thou shalt remain, in midst of other woe".

In the last verses, who will finally manifest will be the urn with the classic axiom "Beauty is truth, truth beauty", which summarizes everything that is essential in life. The conquest of Beauty leads to the conquest of Truth, that is, man can only have access to what is eternal and perfect, through art, the only form of knowledge that leads to the Absolute. As a result, in closing the poem, Keats no longer addresses the urn, but a "ye" that is all of humanity: "Ye know on earth, and all ye need to know".

A further aspect needs to be considered, if we think that the urn will serve to awaken in the poet a world of unknown sensations that, in turn, will be directed at the interlocutor. Keats, wanting to express feelings about passion, life, death, about the feeling of the passage of time, does not do so directly. On the contrary, he chooses as his starting point a Greek urn; through its sculpted images, it will awaken in the poet a chain of feelings that will culminate in the conquest of an absolute. The figure of ekphrasis, used here with great mastery, will serve to establish a bridge between the past and the present. Keats, when contemplating the artifact that is, at the same time, a sculpture and a painting, makes the inanimate images come to life, but not only that, as he activates implicit ones, which the graphic art object, by itself, could never express. The urn is silent in its frozen images, but for this very reason, due to its beauty and suggestion of eternity, it has the power to activate the exalted imagination of the poet, which will give life to the figures and representations of unfinished movements and also free a new sensation, still incubated in his imagination, and only awakened by the contemplation of the Greek vase, a "objective correlative", according to Elliot's concept:

The only way of expressing emotion in the form of art is by finding an "objective correlative"; in other words, a set of objects, a situation, a chain of events which shall be the formula of that particular emotion; such that when the external facts, which must terminate in sensory experience, are given, the emotion is immediately evoked [7].

Something similar happens with the interlocutor: after contemplating this representation of another representation, he will see new sensations awaken in him that will lead him to the realm of the Absolute.

\subsection{Alberto de Oliveira}

Alberto de Oliveira (alias of Antônio Mariano de Oliveira, Saquarema, 1857 - Niterói, Brazil, 1937) composed the ekphrastic piece reproduced below, referring to a Greek vase. He followed the precepts of the so-called Parnassian school, which puts him in stark contrast with Keats, curbing emotion and assuming toward the aesthetic object an Olympian attitude in which the descriptive and objective aspects are crucial.

Greek Vase

This one of golden reliefs, crafted

By divine hands, brilliant cup, one day,

Already to the gods to serve as tired,

Coming from Olympus, a new god served.

It was the poet of Teos who suspended it

So, and now full and now exhausted,

The friendly cup to his fingers clinked,

All with purple petals thatched.

Later... But the glasswork is amazing,

Touch it, and to the ear bringing it closer, to the edges

You'll hear it fine, melodious and sweet,

Unknown voice, as if the old lyre

Were the enchanted music of the strings,

As if this Anacreonte's voice were. ${ }^{1}$

To write the sonnet Oliveira must have seen a Greek vase, or printed reproductions, or else read ekphratic texts by other authors. We just do not have the elements to determine where his inspiration came from. So let's start from the assumption that the sonnet would be about a fictitious vase, created by the poet's imagination.

The poem fulfills the dictates of Parnassianism, namely, objectivity, descriptivism, anti-passionalism, transparency of signs and the cult of classical exoticism. Oliveira's ekphrastic creation suffers from a limitation, insofar as, due to predominance of description and the poverty of metaphors, the poem is dominated by a kind of prosaism. "Greek Vase" is provided with decorative elements - "golden reliefs", "shining cup", "purple petals thatched " - and limited narrative action, in reference to the poet's movement in raising the up and making it tinkle. Thus the sculptural object is no more than a metaphor for the poem itself. Just as the cup, if touched, releases a certain sound - the music of the lyre and the voice of the Greek poet - the sonnet conjures up, visually and sonically, images of an authentic Greek vase and images of the pagan world, with its gods and poets. And this,

\footnotetext{
1 Vaso Grego "Esta de áureos relevos, trabalhada/De divas mãos, brilhante copa, um dia,/Já de aos deuses servir como cansada,/Vinda do Olimpo, a um novo deus servia.//Era o poeta de Teos que a suspendia/Então, e, ora repleta ora esvasada,/A taça amiga aos dedos seus tinia,/Toda de roxas pétalas colmada.//Depois... Mas o lavor da taça admira,/Toca-a, e do ouvido aproximando-a, às bordas/Finas hás de lhe ouvir, canora e doce,//gnota voz, qual se da antiga lira/Fosse a encantada música das cordas,/Qual se essa voz de Anacreonte fosse!”. (p. 216) [10] (Translated by A.C.G.).
} 
according to the author, could only happen through art. Oliveira's ekphrastic sonnet has a metalinguistic character, insofar as the signs, despite mimicking objects from the real world, turn to themselves, to the understanding of the world and poetry itself. Abrams would catalog this tendency as "objective," since the work of art is thought of by isolating it from all external reference points and analyzing it as a selfsufficient entity constituted by its parts in their internal relations and if to judge it only according to criteria intrinsic to its own way of being [1].

\subsection{Wallace Stevens}

In modernity, we draw attention to the poem "Anedocte of the Jar" by Wallace Stevens (Reading, Pennsylvania, 1879 Hartford, 1955), in which the ekphrastic description of a kind of vase, actually a jar, is noted:

Anedocte of the Jar

I placed a jar in Tennessee,

And round it was, upon a hill.

It made the slovenly wilderness

Surround that hill.

The wilderness rose up to it,

And sprawled around no longer wild.

The jar was round upon the ground

And tall and of a port in air.

It took dominion everywhere.

The jar was gray and bare.

It did not give birth of bird or bush

Like nothing else in Tennessee [9, 14].

What stands out in the American poet's text, more than the vase itself, devoid of decorative elements (it is just "gray and bare"), is the fact that the poet composes an ekphrasis about emptiness that operates on nothing and thus results in an ironic and paraphrastic poem. This text about the jar "provides an allegory and critique of its own generic identity and could almost be understood as a parody of the classic ekphrastic object" [9]. The vase does not have elaborate drawings or sculpted figures that might allow the development of pastoral and warrior stories, as in Theocritus, or enable the awakening of high feelings, as in Keats, or even the recovery of the pagan world, as in Oliveira. On the contrary, it seems to be simply a utilitarian object, massproduced for everyday use and thus lacking in decorative vallue, as well as in any individuality that might arouse a viewer's artistic gaze.

But in the poem, the fact that the jar is placed in another environment alters such utilitarianism, as the poet suggests that the jar "took dominion everywhere." The "poetic self" procedure resembles that of the Dadaists, since, by eliminating the purpose of the jar and locating it in a place where it will be "useless," it creates, for better or for worse, an art object, similar to Duchamp's urinal. As a result, it takes possession of the hill and civilizes it, and this civilizing aspect can even be seen in the way it acts on the "slovenly wilderness" which, imitating the object's round shape, also surrounds the hill with its circularity. On the other hand, the word "dominion", in addition to its clear sense of "domain", used to designate a well-known brand of jars, or canning jars, so that the image of the generic jar as a symbol of civilized activity is crossed here with the allusion to a specific domestic object, both out of place in the "wilderness." The jar ends up influencing the environment, helping to create a dichotomy between the uncivilized and the civilized, or even, imprinting an artistic side to what is wild. In other words, the vase composes the landscape, offers it a certain interior ordering, because, where before there was wild nature, now there is a "garden." And is the subject of the poem that gives it an artistic function which, individualizing it, placing it on top of a hill, makes it reign over the landscape and even modify wild nature itself, imposing its shape. round and civilized. Due to the poet's intervention, the jar behaves as a unique and differentiated object, and, consequently, will serve as a means for the ironic commentary on the poem that goes from the jar to the surrounding space. After all, the emptiness of the artifact, which "did not give of bird or bush," extends to the state of Tennessee, in Stevens's view a poor and uninteresting place, perhaps like the gray vase itself.

Through irony, the poet is contesting the tradition and/or the exhaustion of a genre, writing his anti-ekphrasis. The descriptive element, essential in this rhetorical figure, is minimal, because the vase is marked by an absolute triviality, this triviality present in its traditional and common circular shape, its lack of decorative elements and its monotonous gray color. The contemplation of this object, which is only artistic (or pseudo-artistic), when displaced from its utilitarian function and placed in a different environment, other than the familiar, the domestic one, consequently provokes a differentiated reflection of the poetic-self, even if from the unartistic elements.

\section{Conclusion}

We may conclude that Stevens's text, compared to the others - which, each in its own way, constitute classic descriptions of a noble object - may be considered a parody or the reverse of the classic ekphrastic poem for four main reasons. First, it does not include a artistic object itself, which attracts the eye due to its unique, differentiated and beautiful appearance. Secondly, the object only becomes artistic, due to the intervention of the poet who removes its utilitarian aspect by removing it from the domestic environment. Third, as a result of this fact, the poet, when constructing the ekphrasis, potentiates the implicit, suggested by the neutrality of the jar, but not to sing the sublime, the transcendental, but rather to bring to light a critical element. And finally, this critical element branches out, contemplating the world of representations, the jar and its ekphrastic description and the real world, in this case, the state of Tennessee.

In this way, Stevens' poem, at the same time that it constitutes the highest point that an ekphrastic poem can reach, because it composes about emptiness, about nothingness, also constitutes the dismantling of a tradition. Hence its modernity or even post-modernity, when the poet 
recycles, through irony, a convention.

\section{References}

[1] ABRAMS, Meyer Howard. El espejo y la lámpara. Buenos Aires: Editorial Nova, 1962.

[2] BOZEC, Yves. Ekphrasis de mon coeur, ou l'argumentation par la description pathétique, Littérature, Paris: Larousse, $\mathrm{n}^{\circ}$ 111, out. 1998: 111-124.

[3] CASSIN, Barbara. L'effet sophistique. Paris: Gallimard, 1995.

[4] DESBORDES, Françoise. La rhétorique antique. Paris: Hachette, 1996, p. 135, cited in Yves Le Bozec, Ekphrasis de mon coeur, ou l'argumentation par la description pathétique, Littérature, Paris: Larousse, $\mathrm{n}^{\circ}$ 111, out. 1998: 111-124, p. 111.

[5] HEFFERNAN, James A. W. Ekphrasis and Representation, Baltimore: The John Hopkins University Press, New Literary History, 1991.

[6] HORÁCIO, F. Arte poética. Lisboa: Clássica Editora, s.d.

[7] ELIOT, T. S. "Hamlet and His Problems," Selected Essays, London: Baer \& Faber, 1961, p. 145.

[8] KEATS, John. Selected Poems. New Jersey: Random House, 1993.
[9] MITCHELL, Willian John Thomas. La écfrasis y el otro. Teoría de la imagen. Madrid: Akal, 2009.

[10] MOISÉS, Massaud. A literatura brasileira através dos textos. $10^{\mathrm{a}}$ ed., São Paulo: 1983.

[11] MOISÉS, Massaud. Albano Martins: a poética do olhar. $A$ literatura como denúncia. São Paulo: Íbis, 2002.

[12] MOSES, Henry. A Collection of Antique Vases, Altars, Paterae. London: Books on Demand, 2013.

[13] NOGUEIRA, Érico. Vontade, contenda e poesia nos Idílios de Teócrito, tese de doutorado defendida na USP em 2012.

[14] STEVENS, Wallace. Anedocte of the Jar, cited in MITCHELL, Willian John Thomas, La écfrasis y el otro. Teoría de la imagen. Madrid: Akal, 2009.

[15] THEOCRITUS. Translated into English verse, by C. S. Calverley, the Project Gutenberg EBook of Theocritus, https://www.gutenberg.org/files/11533/11533-h/11533h.htm\#IDYLL_I 2004 [EBook \#11533].

[16] THÉON, Aelius. Exercices préliminares, cited in DESBORDES, Françoise. La réthorique antique. Paris: Hachette, 1996, p. 135. 